\title{
PELAKSANAAN PENDIDIKAN AGAMA ISLAM BAGI NARAPIDANA KASUS KORUPSI
}

\author{
Hasbiyallah $^{1)}$, Siti Fadhillah Asy-Syari ${ }^{2)}$ \\ Universitas Islam Negeri Sunan Gunung Djati, Bandung, 40614 \\ Email: hasbiyallah@uinsgd.ac.id, sitifadhillah.asyari@yahoo.com
}

\begin{abstract}
In an effort to eradicate corruption cases in Indonesia is reduced, an idea emerges to include the role of Islamic religious education in Correctional Institutions so that criminal inmates can accept their mistakes with a form of self-awareness to improve themselves. This study aims to determine the implementation of Islamic religious education in Women's Class IIA class of planning, processes, and supporting factors and inhibiting the implementation of Islamic education for inmates of corruption cases. This research uses qualitative method with case study research. In data collection, the author uses observation methods, interviews, field notes and documentation. While to analyze its data with descriptive interpretation. The results of research conducted by the author can be submitted are: First, the planning implementation of Islamic religious education consists of short-term, medium-term and long-term. Second, the process of implementation of Islamic religious education in Penitentiary has been scheduled by the prison from Monday to Saturday every morning at 07.30 to 11.30. Third, the supporting factors of educators are filled by the agency and various religious organizations, The inhibiting factor is a means that is always focused in the hall so that the situation and conditions are noisy.
\end{abstract}

Keywords:

Islamic education, prisoners of corruption cases, Correctional Institution

\begin{abstract}
Abstrak :Dalam upaya memberantas kasus korupsi di Indonesia ini berkurang, timbulah sebuah gagasan untuk memasukan peran pendidikan agama Islam di Lembaga Pemasyarakatan sehingga Narapidana yang melakukan tindak kriminal dapat menerima kesalahan mereka dengan bentuk kesadaran diri untuk memperbaiki diri. Penelitian ini bertujuan untuk mengetahui pelaksanaan pendidikan agama Islam di Lembaga Pemasyarakatan wanita kelas IIA yaitu tentang perencanaan, proses, dan faktor pendukung dan penghambat pelaksanaan pendidikan agama Islam bagi narapidana kasus korupsi. Penelitian ini menggunakan metode kualitatif dengan jenis penelitian studi kasus. Dalam pengumpulan data, penulis menggunakan metode observasi, wawancara, catatan lapangan dan dokumentasi. Sedangkan untuk menganalisis data nya dengan penafsiran deskriptif. Hasil penelitian yang dilakukan penulis dapat disampaikan yaitu : Pertama, perencanaan pelaksanaan pendidikan agama Islam terdiri dari jangka pendek, jangka menengah dan jangka panjang. Kedua, proses pelaksanaan pendidikan agama Islam di Lembaga Pemasyarakatan telah dijadwalkan oleh pihak lapas dari hari senin sampai hari sabtu setiap pagi pukul 07.30 sampai dengan 11.30. Ketiga, faktor pendukungnya tenaga pendidik/dai yang diisi oleh pihak instasi dan berbagai organisasi keagamaan, Faktor penghambatnya adalah sarana yang selalu terfocus di aula serba guna sehingga situasi dan kondisinya bising.
\end{abstract}

\section{Kata Kunci:}

PAI, Narapidana Kasus Korupsi, Lembaga Pemasyarakatan

\section{PENDAHULUAN}

Tindak pidana seperti halnya korupsi telah meluas dihampir seluruh masyarakat di Indonesia, perkembangannya terus meningkat dari tahun ke tahun, jumlah kasus yang 
terjadi dan jumlah kerugian negara yang diakibatkan serta bentuk pelaksanaan tindak pidana yang dilakukan semakin sistematis dan korupsi sudah merupakan patalogi social (penyakit sosial) yang sangat berbahaya yang mengancam semua aspek kehidupan bermasyarakat, berbangsa dan bernegara (Denny Indrayana,2008).

Lembaga Komisi Pemberantas Korupsi (KPK) adalah salah satu Lembaga yang giat menumpas dan menangkap para pelakunya melalui Operasi Tangkap Tangan (OTT) dalam upaya meminimalisir angka kejahatan tindak korupsi. Setelah penangkapan, para koruptor masuk ke dalam Lembaga Pemasyarakatan/Rumah Tahanan Negara yang berfungsi menampung para tindak kriminal seperti: pembunuhan, pemerkosaan, narkoba, termasuk para koruptor.

Korupsi dalam pandangan Agama Islam merupakan suatu perbuatan yang keji. Bahkan korupsi bisa dibilang sebanding dengan narkoba atau terorisme, karena dampak dari perbuatan korupsi itu merugikan orang banyak secara keseluruhan. Dalam upaya memberantas kasus korupsi di Indonesia ini berkurang, timbulah sebuah gagasan untuk memasukan peran pendidikan agama Islam di Lembaga Pemasyarakatan sehingga Narapidana yang melakukan tindak kriminal dapat menerima kesalahan mereka dengan bentuk kesadaran diri untuk memperbaiki diri.

Pelaksanaan pendidikan Agama Islam bagi narapidana di Lembaga Pemasyarakatan wanita kelas IIA Sukamiskin Bandung dapat berperan memberikan nilai-nilai positif dalam mengubah perilaku atau tindakan mereka terutama pada kasus korupsi. Kegiatan di Lembaga Pemasyarakatan bukan sekedar untuk menghukum atau menjaga narapidana tetapi adanya proses penyelenggaraan pembinaan bagi narapidana, berupa pembinaan kepribadian dan kemandirian, salah satu yang termasuk ke dalam pembinaan kepribadian yaitu pembinaan kerohanian.

Program pembelajaran kerohanian berada pada naungan Departemen Agama. Dalam Pelaksanaan pendidikan Agama Islam yang diberikan kepada narapidana meliputi tiga dimensi diantaranya dimensi akidah, ibadah dan akhlak.

Dilihat dari tiga dimensi tersebut maka pendidikan agama Islam berperan mengatasi setiap permasalahan-permasalahan kehidupan manusia termasuk dalam mengatasi masalah tindakan korupsi, sehingga timbulah kesadaran dalam diri mereka bahwa perbuatan mereka tidak benar karena sudah melampaui batas norma dan etika dalam hidup bersama di suatu masyarakat serta menimbulkan rasa tidak aman dan kerugian harta benda dan kerusakan mental bagi para korbannya.

Sebagaimana dikemukakan pada latar belakang diatas, pelaksanaan pendidikan agama Islam dapat di tela'ah melalui tiga aspek, yakni bagaimana perencanaan, proses, faktor pendukung dan penghambat di dalam pelaksanaan pendidikan agama Islam bagi narapidana kasus korupsi di Lembaga Pemasyarakatan Wanita kelas IIA Sukamiskin Bandung.

Berdasarkan rumusan masalah di atas, secara khusus penelitian ini bertujuan untuk memperoleh data dan informasi terkait dengan perencanaan, proses, faktor pendukung dan penghambat di dalam pelaksanaan pendidikan agama Islam bagi 
narapidana kasus korupsi di Lembaga Pemasyarakatan Wanita kelas IIA Sukamiskin Bandung.

Adapun teori yang di gunakan dalam penelitian pelaksanaan pendidikan agama Islam yang di laksanakan oleh Lembaga Pemasyarakatan ini terdiri dari pendidikan agama Islam, Lembaga Pemasyarakatan, narapidana, tindak pidana korupsi. Pendidikan agama Islam Secara etimologi pendidikan agama Islam sering diartikan dengan pendidikan yang berdasarkan ajaran Islam (Ahmad Tafsir, 2004). Pendidikan Islam secara terminologi (istilah) adalah usaha dan kegiatan yang dilakukan oleh Nabi Muhammad SAW dalam menyampaikan seruan agama dengan berdakwah, menyampaikan ajaran, memberi contoh dan menciptakan lingkungan sosial yang mendukung pelaksanaan ide pembentukan pribadi muslim (Zakiyah Darajat, 1996). Dasar pendidikan agama Islam yaitu Al-Qur'an dan Sunnah (Hadits), 1) Al-Qur'an, AlQur'an memandang bahwa korupsi termasuk perbuatan fasad atau perbuatan yang dapat merusak tatanan kehidupan. Al-Fasad sendiri dapat diterjemahkan sebagai segala perbuatan yang menyebabkan hancurnya kemaslahatan dan kemanfaatan hidup, seperti membuat teror yang menyebabkan orang takut, membunuh, melukai dan mengambil atau merampas harta orang lain. Berdasarkan pendapat tersebut, ditegaskan bahwa korupsi sama buruk dan jahatnya dengan terorisme (Mansyursemma, 2008). 2) Sunnah (Hadits), Rasul saw pernah mengingatkan dalam hadits shahih yang artinya: sesungguhnya kehancuran umat-umat sebelum kalian ialah dikarenakan mereka membiarkan koruptor "kelas kakap" berkeliaran tanpa hukum apa-apa. Sebaliknya bila yang melakukan korupsi itu rakyat kecil "kelas teri" mereka tegakan hukum sesuai aturan yang berlaku (HR Bukhari Muslim, Abu Daud, An-Nasai, Ahmad, dll).

Hadits tersebut menginformasikan bahwa perbuatan korupsi atau pencurian, tidak hanya membahayakan diri sendiri, melainkan juga orang lain mengingat dahsyatnya bahaya korupsi, maka pantas sekali hukumannya di dalam As-Sunah, siapapun yang bersalah harus dihukum sesuai aturan yang berlaku. Tidak ada yang kebal hukum, baik penguasa maupun rakyat jelata, atasan dan bawahan. Semua harus dihukum jika bersalah, sesuai berat ringannya kesalahan yang mereka lakukan. Sedangkan tujuan pendidikan Islam adalah "membentuk manusia yang berjasmani kuat atau sehat dan terampil, berotak cerdas dan berilmu banyak, berhati tunduk kepada Allah, serta mempunyai semangat kerja yang hebat, disiplin yang tinggi dan pendirian yang teguh" (Syahminan Zaini, 1986).

Konsep pendidikan agama Islam mencakup tiga unsur diantaranya akidah, ibadah dan akhlak. Pertama akidah yakni Korupsi itu mempunyai keterkaitan dengan akidah sesorang, yang bertepatan dengan akidah dalam mengimani hari akhir karena Korupsi itu perbuatan yang akan mengakibatkan seseorang yang melanggar aturan akidah islam yang akan mendapatkan hukuman atau ganjaran pada hari akhir, kelak sehingga mereka akan mendapatkan balasan yang setimpal atas perbuatan dimasa hidup di dunia. Kedua Ibadah yakni Jika seluruh kegiatan hidup sesorang dipahami sebagai ibadah, maka setiap keputusan tindakan yang dilakukan cenderung berhati-hati, adapun hubungannya dengan ibadah dalam konteks korupsi yakni, pertama kesadaran moralitas 
dimanfaatkan untuk membentuk watak seseorang didalam membedakan hal yang baik dan buruk salah dan benar, serta yang hak dan bathil, kedua iman diimplementasikan seseorang dalam proses menjalani sisa-sisa hidupnya di dunia. Ketiga Akhlak yakni perilaku atau sikap budi pekerti yang sesuai dengan ajaran agama Islam, ada tiga perilaku terbesar yang memicu munculnya korupsi yakni matrealistik, kapitalistik dan hedonistik, ketiga sifat itu yakni pemujaan kemewahan duniawi tetapi hal tersebut bisa diantisipasi oleh akhlak husn khuluq (akhlak yang baik) akhlak yang baik itu adalah akhlak yang antikorupsi, contohnya tidak mengambil harta yang bukan haknya dan tidak zholim terhadap harta nya. Korupsi merupakan satu penyakit masyarakat yang harus diberantas, sebab dapat menghancurkan seluruh jaringan keseimbangan manusia dalam bermasyarakat. Bisa dikatakan bahwa yang kaya bertambah kaya dan yang miskin semakin miskin. Perilaku ini sedikit demi sedikit menggerogoti moralitas manusia yang dibimbing agama. Hukum perbuatan korupsi menurut pendapat ulama fiqih, secara aklamasi dan konsensus (Ijma') adalah haram karena bertentangan dengan prinsip maqashidussy syari'ah. Perbuatan korupsi merupakan perbuatan curang dan penipuan yang berpotensi merugikan keuangan Negara dan kepentingan publik (masyarakat) yang dikecam oleh Allah swt dengan hukuman setimpal di akhirat ( Setiawan Budi Utomo, 2003). Agama Islam sangat menjujung tinggi akan arti kesucian, sehingga sangatlah rasional jika memelihara keselamatan (kesucian) harta termasuk menjadi tujuan pokok hukum Islam, karena mengingat harta mempunyai dua dimensi, yakni dimensi halal dan dimensi haram. Perilaku korupsi adalah harta berdimensi haram karena korupsi menghalalkan sesuatu yang diharamkan, dan korupsi merupakan wujud manusia yang tidak memanfaatkan kekuasaan dalam memperoleh rezeki Allah. Secara teoritis kedudukan korupsi merupakan tindakan kriminal (jinayah atau jarimah) dimana bagi pelakunya diancam dengan hukuman hudud (had) dan juga hukuman ta'zir.

Sistem pemasyarakatan berfungsi menyiapkan Warga Binaan Pemasyarakatan agar dapat berintegrasi secara sehat dengan masyarakat, sehingga dapat berperan kembali sebagai anggota masyarakat yang bebas dan bertanggung jawab (UndangUndang No. 12 Tahun 1995 Pasal 3). Selanjutnya tujuan dari pemasyarakatan supaya narapidana menjadi baik dan setelah habis menjalani pidanannya agar tidak lagi melanggar hukum dan menjadi recidivis. Di samping itu supaya mereka turut aktif membangun Negara dan setelah habis menjalani masa pidananya sanggup menghadapi dan mengatasi segala tantangan hidup. Lebih jauh lagi tujuan pemasyarakatan adalah agar supaya warga binaan mentaati aturan agama baik semasa menjalani masa pidana maupun setelah habis menjalani masa pidana (Afifudin, 1977).

Lembaga Pemasyarakatan merupakan sebuah institusi korektif, sebagai bagian akhir dari sistem peradilan pidana. Lembaga Pemasyarakatan juga berfungsi sebagai tempat memproses (memperbaiki) seseorang (people processing organitation/PPO), dimana input maupun output-nya adalah manusia yang dilabelkan sebagai "penjahat". Sistem pemasyarakatan berfungsi menyiapkan Warga Binaan Pemasyarakatan agar dapat berintegrasi secara sehat dengan masyarakat, sehingga dapat berperan kembali sebagai anggota masyarakat yang bebas dan bertanggung jawab. Meskipun seorang 
narapidana telah kehilangan kemerdekaan bergeraknya atas suatu putusan hakim, namun tetap sebagai warga negara yang masih memiliki hak-hak asasi seperti halnya wargawarga lainnya. Narapidana hanyalah manusia yang tersesat didalam perjalanan hidupnya. Bahkan sebagai manusia atau warga yang telah tersesat dalam perjalanan hidupnya sangatlah perlu mendapatkan perlindungan. Perlindungan tersebut dilakukan dengan usaha pengembangan dan kecerdasannya sebagai anggota masyarakat untuk masa depannya. Pengetahuan dan keterampilan yang diperioleh selama menjalankan pidana dapat memupuk rasa percaya diri sendiri/harga dirinya serta dapat dipergunakan sebagai bekal hidupnya sesudah habis menjalani masa pidananya, dengan demikian fungsi Lembaga Pemasyarakatan yaitu sebagai lembaga tempat para narapidana menjalani masa pemidanaan, khususnya pidana penjara.

Masalah yang timbul selama di penjara, misalnya mengendalikan kejahatan narkotika dari dalam penjara. Ada juga yang melakukan kejahatan sebagai hasil dari didikan teman sel-selnya seperti cara membuat kunci letter T. Kasus ini menunjukkan bahwa pembinaan di Lembaga Pemasyrakatan, bukannya membuat dia sadar atas kesalahannya, kemudian memperbaiki diri, malahan dia mendapatkan pelatihan cara untuk melakukan kejahatan. Kasus-kasus lain seperti kebebasan seksual yang melibatkan narapidana. Ada yang homoseksual, seks dengan hewan, dengan PSK, peredaran majalah porno, terjadi Lembaga Pemasyarakatan (Taufik, 2018). Kasus bunuh diri, ada yang juga berhasil melarikan diri ketika kondisinya memungkinkan dengan memanjat tembok gedung penjara, bahkan ada yang kabur melalui pintu depan dengan berpura-pura ditengok kerabatnya. Ketika penjaga lengah mereka berhasil kabur dengan menembak sipir penjara. Pembinaan di Lembaga Pemasyarakatan tidak membuat mereka sadar akan kejahatan yang dilakukannya. Tentunya banyak faktor yang menyebabkan mereka berperilaku seperti ini, tetapi salah satu faktor penyebab yang sangat kuat adalah mereka tidak mendapatkan pembinaan yang memadai sesuai dengan yang dibutuhkan, yaitu suatu pembinaan yang dapat menyesali diri karena telah berbuat salah dan berupaya tidak lagi menggulang perbuatan salah sebagaimana yang pernah dilakukan sebelumnya.

Narapidana adalah terpidana yang menjalani pidana hilang kemerdekaannya (Undang-Undang No. 12 Tahun 1995, pasal 1), tapi ada hak-hak narapidana yang tetap dilindungi dalam sistem pemasyarakatan Indonesia. Faktor penyebab jadi narapidana, 1) dalam kondisi terpaksa, Orang yang dalam situasi dan kondisi yang serba sulit dapat mengubah seseorang yang tadinya tidak ada keinginan berbuat jahat menjadi pelaku tindak kejahatan, 2) adanya kesempatan berbuat jahat, Ada orang-orang yang bisa berubah menjadi seorang penjahat jika muncul suatu peluang besar dalam melakukan tindak kejahatan. Jika dihitung-hitung resiko tertangkap tangan ketika melakukan aksi kejahatan kecil, serta kecilnya peluang untuk tertangkap setelah dilakukan penyidikan dapat memperbesar dorongan seseorang untuk berbuat jahat, 3) dalam suatu tekanan pihak tertentu, Seseorang yang dipaksa untuk melakukan suatu tindak kejahatan, bisa saja melakukan perbuatan jahat kepada orang lain dan biasanya orang yang berbuat jahat karena alasan ini merasa tekanan batin dan ingin menolak berbuat jahat pada orang lain. 
Adapun hak dan kewajiban bagi narapidana selama berada di dalam Lembaga Pemasyarakatan, yaitu: narapidana berhak, 1) Melakukan ibadah sesuai dengan agama dan kepercayaannya, 2) mendapat perawatan, baik perawatan rohani maupun jasmani, 3) Mendapatkan pendidikan dan pengajaran. Sedangkan Narapidana wajib mengikuti secara tertib program pembinaan dan kegiatan tertentu. Kegiatan di Lembaga Pemasyarakatan Wanita kelas II A Sukamiskin Bandung terbagai menjadi 2 bagian, yaitu 1) pembekalan keterampilan, seperti: menjahit, salon, merajut baik itu merajut tas, topi, gelang tangan, menari, menyanyi, memasak, dan keterampilan lainnya, 2) pembinaan kerohanian, seperti: mengikuti tausyiah, pembelajaran iqra, pesantren shalihah, shalat berjamaah, memperingati hari besar Islam diantaranya Isra Miraj, kemerdekaan Republik Indonesia 17 Agustus 1945, serta perayaan hari Ibu.

Menurut KBBI (Kamus Besar Bahasa Indonesia) menyebutkan bahwa korupsi bermakna penyelewengan atau penggelapan (uang Negara atau Perusahaan) untuk kepentingan pribadi atau orang lain (Departemen Pendidikan dan Kebudayaan, 1989). Penanganan masalah korupsi di Indonesia telah menimbulkan dilema sosial akibat manajemen korupsi dalam birokrasi pemerintahan dan swasta yang menyebabkan korupsi membudaya. Pada sisi lain, proses penegakan hukum dalam memberantas korupsi yang dilakukan oleh pemerintah amat lamban. Kalaupun bisa sampai ke pengadilan, lebih banyak mengecewakan masyarakat. Sehingga, pemecahan yang dapat dijadikan bahan pertimbangan guna mengatasi dilema yang menimpa masyarakat dalam memberantas korupsi menjadi tanggung jawab bersama.

Sebagaimana halnya korupsi yang sangat beragam, begitupun dengan bentuk korupsi. Menurut Hussain Alatas, bentuk-bentuk korupsi mencakup penyuapan (bribery), pemerasan (exstortion), dan nepotisme. 1) penyuapan, ,merupakan sebuah perbuatan kriminal dimana seseoarang dilimpahi pemberian dengan maksud agar penerima pemberian tersebut mengubah perilaku sedemikian rupa sehingga bertentangan dengan tugas dan tanggung jawabnya 2) pemerasan, bentuk korupsi ini mengandung arti penggunaan ancaman kekerasan atau penampilan informasi yang menghancurkan guna membujuk seseorang agar mau bekerja sama. Dalam hal ini pemangku jabatan bisa menjadi pemeras atau korban pemerasan, 3) nepotisme, berarti memilih keluarga atau teman dekat dengan pertimbangan hubungan, bukan karena kemampuannya.

Pada umumnya, tindak pidana korupsi terjadi karena adanya kesempatan dan adanya niat untuk melakukan tindak pidana tersebut. Kesempatan untuk korupsi perlu dipersempit dengan memperbaiki sistem. Sementara niat untuk melakukan korupsi lebih banyak dipengaruhi oleh sikap mental atau moral dari para pejabat atau pegawai. Banyak pejabat atau pegawai, mempunyai sikap yang keliru tentang sah atau tidaknya suatu penghasilan atau halal haramnya suatu sumber pendapatan. Peluang berkorupsi ada, individu juga sudah kehilangan moralitas, dan sistem juga mendukung atas terjadinya tindakan korupsi, maka disinilah sebuah tindakan korupsi akan menjadi sebuah kenyataan. Dengan demikian, praktik korupsi terjadi karena adanya motif pelaku yang biasanya berupa hal-hal sebagai berikut: 1) keinginan untuk memupuk harta sebanyak- 
banyaknya (materialisme), 2) keinginan untuk memenuhi seluruh kebutuhannya (konsumerisme), 3) takut terhadap kemiskinan, ingin cepat kaya dalam waktu cepat. Oleh karenanya, pada abad ke-14, sejarawan mengatakan bahwa akar penyebab korupsi adalah nafsu untuk hidup bermewah-mewah dikalangan kelompok yang berkuasa. Nafsu berkuasa yang sangat tinggi tentu akan menyebabkan perilaku dan tindakan yang menyimpang. Biasanya amanat untuk menjalankan tugas dan tanggung jawab sangat tinggi, kondisi ini sudah tidak menjadi sebuah realitas. Amanat kemudian harus digadaikan atas nama hedonisme, yang lebih dekat dengan gemerlapnya dunia dan kebendaan. Hedonisme yang menawarkan kebahagiaan dan kesenangan yang semu sudah membius manusia untuk berperilaku dan bertindak yang salah sehingga ini menyebabkan kerusakan bagi kepentingan bersama (Ibnu Khaldun, 2000).

Dalam pasal 3 diterangkan bahwa "setiap orang yang dengan tujuan menguntungkan diri sendiri atau orang lain atau suatu korporasi, menyalahgunakan kewenangan, kesempatan, atau sarana yang ada padanya karena jabatan atau kedudukan yang dapat merugikan keuangan negara atau perekonomian negara, dipidana dengan pidana penjara seumur hidup atau pidana penjara paling singkat 1 tahun dan paling lama 20 tahun dan denda paling sedikit Rp.50.000.000,00 (lima puluh juta rupiah) dan paling banyak Rp.1.000.000.000,00 (satu miliar rupiah)".

Islam mengajarkan tentang hidup santun, menghargai, hormat, kasih dan sayang kepada orangtua, guru, orang yang lebih tua, atau sesama. Menghindari dari perbuatan tercela seperti berbohong, tidak jujur, tidak amanah (korupsi). Selalu mendekat pada Allah melalui kegiatan spiritual seperti banyak berzikir, shalat berjamaah, membaca AlQur'an dan lain-lain, sehingga nilai-nilai Islam terasakan dalam kehidupan sehari-hari. Dengan demikian, menerapkan nilai Islam secara benar, sebenarnya merupakan menjauhkan dari tindakan korupsi. Korupsi dalam sudut pandang nilai-nilai ke-Islaman, merupakan perbuatan pengkhianatan terhadap amanah dan tanggung jawab yang diberikan rakyat. Korupsi juga dapat dikatakan suatu tindakan memakan harta sebagian yang lain dengan jalan yang bathil, karena korupsi menghabiskan milik negara yang seharusnya digunakan untuk kepentingan rakyat.

Sebagaimana diketahui, meski korupsi merupakan peristiwa hukum, tapi korupsi tidaklah sekedar persoalan hukum semata. Ada banyak faktor yang terlibat dan membentuk perilaku mengapa muncul perilaku korup. Selain karena ada faktor keserakahan penguasaan harta benda, juga terkait dengan problema kebudayaan yang terwarisi dari sikap, persepsi dan perilaku yang menjadi penyimpangan kebiasaankebiasaan dalam pengelolaan kewenangan kekuasaan. Maka model yang cocok adalah pendidikan korupsi sebagai bentuk pencegahan tindak krimanal korupsi, diantaranya sebagai berikut: Pertama, internalisasi pendidikan anti korupsi ke dalam sistem pembelajaran. Setidaknya sebagai salah satu pengkondisian agar masyarakat, memiliki kemampuan untuk mencegah terjadinya korupsi. Kedua, peningkatan wawasan masyarakat melalui pembentukan simpul-simpul anti korupsi. Mengapa masyarakat perlu dilibatkan? Bukan sebagai penegak hukum, melainkan sebagai kelompok non pemerintah yang berpartisipasi dalam mengawal pengelolaan pemerintahan yang 
transparan dan bersih. Pendidikan anti korupsi bukanlah sekedar penyebarluasan pengetahuan tentang korupsi, melainkan upaya internalisasi nilai-nilai moralitas publik kepada masyarakat agar mereka memiliki kepedulian terhadap kepemilikan publik (kekayaan negara sebagai milik bersama). Ada tiga (3) hal upaya yang dilakukan dalam rangka keberhasilan menciptakan masyarakat anti korupsi, yakni: 1) pembiasaan dan penciptaan perilaku; 2) internalisasi melalui pendidikan; 3) komitmen bersama yang ditegakkan melalui public policy (kebijakan publik) yang mengarusutamakan kepentingan bersama. Ketiga model pendekatan ini dianggap representatif dalam rangka menciptakan masyarakat anti korupsi. Bercermin dari realitas tersebut, pendidikan jelas merupakan model pencegahan kebudayaan yang paling penting dalam rangka membangun masa depan masyarakat yang anti korupsi. Pembiasaan dan penciptaan perilaku peserta didik yang sejak awal terinternalisasi nilai-nilai yang anti perilaku koruptif, nepotif, dan kolutif, diarahkan pada pola pembiasaan yang berlanjut ketika mereka menjadi bagian penting dalam masyarakat. Pendidikan merupakan strategi kebudayaan yang penting dalam rangka menciptakan generasi muda yang memiliki kejujuran dan anti korupsi.

Strategi atau upaya untuk memberantas korupsi di berbagai sektor diantaranya pendidikan, kesehatan dan birokrasi menurut BPKP dapat dilakukan strategi preventif, detektif dan represif yang perlu dilakukan, sebagai berikut: 1) strategi Preventif, diarahkan untuk mencegah terjadinya korupsi dengan cara menghilangkan atau meminimalkan faktor-faktor penyebab atau peluang terjadinya korupsi. 2) strategi Detektif, diarahkan untuk mengidentifikasi terjadinya perbuatan korupsi. 3) strategi Represif, diarahkan untuk menangani atau memproses perbuatan korupsi sesuai dengan peraturan perundang-undangan yang berlaku.

\section{METODOLOGI PENELITIAN}

Penelitian ini dilakukan dengan menggunakan pendekatan kualitatif, yaitu pendekatan yang diarahkan pada latar dan individu secara utuh dan juga sebagai prosedur penelitian yang menghasilkan data deskriptif yakni suatu penelitian yang berupa kata-kata tertulis dan bukan angka (Faisal Sanapiah,1982). Pendekatan kualitatif digunakan untuk meneliti objek-objek yang alamiah, langsung kepada sumber data, serta yang menjadi instrumen penelitian adalah peneliti itu sendiri.

Metode yang digunakan dalam penelitian ini adalah kualitatif. Artinya, metode ini diusahakan untuk melukiskan dan memaparkan data yang ada secara lebih sederhana berupa akta-kata tertulis atau lisan dari sejumlah orang atau perilaku yang dapat dicermati. Metode ini disesuaikan dengan tujuan penelitian yang hendak dicapai, yaitu dapat memberikan wawasan baru tentang materi-materi pendidikan agama Islam.

Kemudian jenis penelitian yang penulis gunakan yaitu studi kasus karena penelitian ini menggunakan pendekatan kualitatif dan termasuk penelitian studi kasus maka hasil penelitian ini bersifat analisis-deskriptif yaitu berupa kata-kata tertulis atau lisan dari perilaku yang diamati. Sedangkan sumber penelitian ini berasal dari data primer yaitu data yang di peroleh yang diperoleh dari sumber pertama melalui prosedur 
dan teknik pengambilan data yang dapat berupa observasi, wawancara, catatan lapangan, dokumentasi maupun penggunaan instrumen pengukuran yang khusus dirancang sesuai dengan tujuannya. Sedangkan data sekunder adalah data yang diperoleh dari sumber tidak langsung yang biasanya berupa data dokumentasi dan arsip-arsip resmi.

Data penelitian dikumpulkan baik lewat instrumen pengumpulan, observasi, wawancara, catatan lapangan maupun lewat data dokumentasi. Sumber data secara garis besar terbagi ke dalam dua bagian, yaitu data primer data yang diperoleh dari sumber nya langsung dan data sekunder yaitu data yang diperoleh dari sumber tidak langsung yang biasanya berupa data dokumentasi dan arsip-arsip resmi (Saifudin Azwar,2005).

Tempat penelitian yang akan menjadi objek peneliti adalah di Lembaga Pemasyarakatan Wanita Kelas IIA Jl. Pacuan Kuda No. 03 Kelurahan Sukamiskin Kecamatan Arcamanik Kota Bandung. Penelitian ini ditujukan kepada WARNA (Warga Binaan) wanita yang terjerat kasus korupsi. Sedangkan waktu penelitiannya dilaksanakan pada tanggal 13 Februari 2018.

Adapun teknik pengumpulan data dalam penelitian ini, menggunakan beberapa teknik yang dapat digunakan dalam penelitian yakni berupa observasi, wawancara, catatan lapangan dan dokumentasi.

dalam menganalisis data ini, penulis menggunakan teknik analisis dskriptif kualitatif, dimana teknis ini penulis gunakan untuk menggambarkan, menuturkan, melukiskan serta menguraikan data yang bersifat kualitatif yang telah penulis peroleh dari hasil teknik pengumpulan data.

\section{HASIL KAJIAN DAN PEMBAHASAN}

Pertama, perencanaan pelaksanaan pendidikan agama Islam di latar belakangi dengan berbagai masalah yang muncul di Lembaga Pemasyarakatan, salah satu di antaranya korupsi yang sudah mengakar sehingga sulit di hindari oleh para pejabat, karena termotivasi untuk kaya dalam waktu cepat, kemudian kurangnya gaji pegawai negeri dibandingkan kebutuhan yang semakin meningkat. terkadang agama sudah tidak lagi menjadi benteng sehingga mereka tergiur dengan tindakan korupsi tersebut.

Berdasarkan penelitian yang telah dilakukan oleh peneliti, berikut temuan mengenai teori perencanaan pendidikan agama Islam yang diterapkan di Lembaga Pemasyarakatan adalah memakai teori sinoptik, dimana objek perencanaan dipandang sebagai suatu kesatuan yang bulat, dengan satu tujuan yaitu: a) Pemasyarakatan yang professional, b) Petugas pemasyarakatan memiliki kompetensi, integritas dan etos kerja tinggi, c) Warga binaan produktif menuju manusia mandiri yang berdaya guna. Dalam perencanaan di tetapkan jangka waktunya, dari mulai jangka pendek yaitu para tipikor mendapatkan pendidikan tentang bahanya korupsi dalam pandangan agama Islam, jangka menengah yaitu narapidana tipikor menyadari tentang bahayanya korupsi dan dampak melakukan korupsi dalam pandangan agama Islam dan jangka panjang yaitu napi tipikor bertaubat tidak mengulangi lagi tindak kejahatan korupsi dengan penanaman aspek akidah, ibadah dan akhlaknya. Pelaksanaan pendidikan agama Islam terdiri dari: 1) identifikasi kebutuhan terkait dengan hal-hal yang ingin diperoleh 
narapidana yaitu pembinaan kesadaran beragama, 2) perumusan tujuan pelaksanaan PAI yang didasarkan pada kebutuhan narapidana di lapangan, 3) penyusunan program yang terbagi ke dalam beberapan sub kegiatan diantaranya pembinaan mental rohani agama Islam, kegiatan di bulan ramadhan dan kegiatan peringatan hari besar Islam, 4) penetapan bahan materi yang meliputi aspek Akidah, Ibadah dan Akhlak, 5) penggunaan metode yaitu dengan menggunakan metode ceramah, tanya jawab dan diskusi, 6) penggunaan fasilitas yang berupa laptop, in focus, papan tulis, spidol,dan sound sistem, 7) penetapan waktu kegiatan pelaksanaan PAI yang dilaksanakan pada pukul 7.30 WIB sampai dengan $12.00 \mathrm{WIB}, 8)$ koordinasi dengan pihak tenaga pendidik diantaranya pihak Kementrian Agama Kota Bandung dan berbagai organisasi keagamaan.

Kedua, Proses pelaksanakan pendidikan agama Islam di Lembaga Pemasyarakatan dilaksanakan dari hari senin sampai dengan hari sabtu di mulai dari jam 07.30 sampai dengan 11.30 yang bekerja sama dengan kementrian agama kota bandung, majelis ta'lim, organisasi-organisasi keagamaan. Karena di Lembaga Pemasyarakatan tidak ada pegawai khusus yang menjadi pembina keagamaan. Untuk materi yang di sampaikan tidak ada aturan khusus oleh Bimbingan Narapidana atau Anak Didik (BINADIK) kepada tenaga pendidik. Lembaga Pemasyarakatan Wanita Kelas IIA Sukamiskin-Bandung telah melakukan program dan jadwal untuk pelaksanaan Pendidikan Agama Islam, jadwal tersebut merupakan sebuah kepedulian petugas terhadap kesadaran beragama narapidana agar selalu dihiasi atau dibina akidah, akhlak, dan ibadahnya dengan pelaksanaan pendidikan agama Islam secara istiqomah (terusmenerus) dan teratur. Jika pelaksanaan pendidikan agama Islam tidak dijadwalkan dengan berlanjut dan terkoordinir, maka dikhawatirkan narapidana tidak ada peningkatan moralitas yang lebih baik. Para petugas di Lembaga Pemasyarakatan Wanita Klas IIA ini telah banyak melakukan kerjasama dengan berbagai pihak instansi dan berbagai organisasi keagamaan untuk suksesnya pelaksanaan pendidikan agama Islam. Selain itu juga, petugas telah menvariasikan kegiatan atau bentuk-bentuk penyuluhannya, sehingga peneliti mengamati narapidana merasa senang dan tidak jenuh. Pembelajaran yang menyenangkan tersebut juga didukung oleh tenaga pengajar yang profesional dan bergantian. Sedangkan untuk jumlah peserta yang mengikuti kegiatan pendidikan agama Islam baik itu dari narapidana maupun tahanan tidak tetap, maka dalam hal ini jumlahnya kurang lebih 200 warga binaan yang beragama Islam.

Ketiga, faktor yang menjadi pendukung dalam pelaksanaan pendidikan agama Islam, yaitu tenaga pendidik yang profesional dikarenakan berkerjasama dengan kementrian agama Kota Bandung yang terjadwal rutin, organisasi keagamaan seperti tadabur qur'an, muslimah berkah, majelis ta'lim, media dan fasilitas nya yang lengkap. Adapun faktor penghambatnya adalah dipusatkannya kegiatan pelaksanaan di aula serba guna, dikarenakan tidak tersedianya ruangan khusus atau kelas, sehingga sering kali terjadi kebisingan yang berdampak tidak sampainya materi yang disampaikan oleh tenaga pendidik kepada sebagian warga binaan. 


\section{SIMPULAN}

Perencanaan Pelaksanaan Pendidikan Agama Islam di Lembaga Pemasyarakatan Wanita Kelas IIA Sukamiskin-Bandung memiliki tujuan untuk meningkatkan kualitas warga binaan agar menjadi manusia seutuhnya, bertakwa, sehat dan bertanggung jawab pada diri, keluarga dan masyarakat, sehingga dapat mengintegrasikan dirinya ke dalam masyarakat, dapat kembali berperan sebagai anggota masyarakat yang bebas dan bertanggung jawab. Perencanaannya di mulai dari jangka pendek, jangka menengah dan jangka panjang yang terdiri dari identifikasi kebutuhan, perumusan tujuan pelaksanaan PAI, penyusunan program, penetapan bahan materi, penggunaan metode, penggunaan fasilitas, penetapan waktu kegiatan pelaksanaan PAI, dan koordinasi dengan pihak tenaga pendidik.

Proses Pelaksanan Pendidikan Agama Islam bagi narapidana di Lembaga Pemasyarakatan Wanita Kelas IIA Sukamiskin-Bandung telah mengacu pada jadwal yang diberlakukan oleh Subsi Bimbingan Kesehatan Masyarakatan dan Perawatan, yaitu telah memperhatikan aspek-aspek keislaman, seperti aspek Akidah Akhlak, Fiqh, AlQuran Hadits, Sejarah Kebudayaan Islam, dan Pengantar Ilmu Agama Islam, serta penyuluhan hukum yang sampaikan langsung oleh pihak kantor wilayah kementerian hukum dan hak asasi manusia. Pelaksanaan pendidikan agama Islam waktunya diselenggarakan senin sampai dengan sabtu di mulai dari jam 07.30 sampai 11.30. Pembina yang memberikan Pendidikan Agama Islam di Lembaga Pemasyarakatan tersebut, maka terdapat tiga pihak yang melakukan pembinaan. Di antaranya berasal dari Kantor Kementerian Agama Kota Bandung, MTQ (Majelis Tadabur Qur'an), dan Organisasi keagamaan yang masing-masing berada di daerah setempat. Diharapkan pelaksanaan Pendidikan Agama Islam bagi narapidana di Lembaga Pemasyarakatan Wanita Kelas IIA Sukamiskin-Bandung dapat merubah akhlak narapidana dan meningkatkan keimanan mereka kepada Allah swt.

Faktor pendukung dalam proses pelaksanaannya adalah tenaga pendidik yang di isi oleh pihak instansi dan berbagai komunitas, seperti pihak kantor kementrian kota bandung, majelis tadabur Al-qur'an dan Muslimah berkah, serta sarana dan prasarana yang cukup menunjang diantaranya sound system, papan tulis, mic, spidol dan infocus. Adapun faktor penghambatnya yang mengganggu selama proses pelaksanaannya. Di antaranya, Situasi dan kondisi nya terkadang bising saat proses pelaksanaan Pendidikan Agama Islam karena dalam kegiatan tersebut sering kali terganggu dengan pemanggilan kunjungan dari keluarga warga binaan yang melakukan kunjungan. Sebagian warga binaan terlihat tidak fokus dalam kegiatan tersebut dikarenakan lebih disibukan dengan aktifitas merajut, dan curhat dengan teman sesama warga binaan.

\section{DAFTAR PUSTAKA}

Afifudin, M., Pembinaan Agama Teradap Naraidana Dalam Rangka Pelaksanaan Sistem Pemasyarakatan, Jakarta: disampaikan dalam Diskusi Metode Da'wah Terhadap Narapidana yang Diselenggarakanoleh Direktorat Penerangan Agama Departemen Agama RI, 1977. 
Hasbiyallah, Siti Fadhillah Asy-Syari

Ahmad Tafsir. Ilmu Pendidikan dalam Perspektif Islam, Bandung, Remaja Rosda Karya,2004.

Alatas Husaein, Sosiologi Korupsi, Jakarta: LP3ES, 1982.

Denny Indrayana, Hukum di Sarang Koruptor, Kompas, Jakarta, 2008.

Departemen Pendidikan dan Kebudayaan, Kamus Besar Bahasa Indonesia, Jakarta: Balai Pustaka, 1989.

Faisal Sanapiah, Metodologi Penelitian Pendidikan Surabaya: Usaha Nasional, 1982.

Hamid, Edy Suandi dan Muhammad Sayuti, Menyingkap Korupsi, Kolusi dan Nepotisme di Indonesia, Yogyakarta: Penerbit Aditya, 1999.

Ibnu Khaldun. Mukaddimah, Jakarta: Pustaka Firdaus, 2000.

Mansyursemma, Negara dan Korupsi, Jakarta, Yayasan Obor Indonesia, 2008.

Muhammadiyah, Nahdatul ulama Partnership Kemitraan, Koruptor itu kafir, Jakarta, Mizan, 2010.

Puspito, Nanang T, Pendidikan Antikorupsi untuk Perguruan Tinggi, Jakarta: Kemendikbud RI, 2011.

Saifudin Azwar, Metode Penelitian, Yogyakarta: Pustaka Pelajar, 2005.

Syahminan Zaini, Prinsip-prinsip dasar Konsepsi Pendidikan Islam, Jakarta, Kalam Mulia, 1986.

Taufik, A., Penjara, the untold stories Jakarta: Ufuk Press, 2018.

Undang-Undang No. 12 Tahun 1995, Tentang Sistem Pemasyarakatan.

Zakiyah Darajat. Ilmu Pendidikan Islam, Jakarta, Bumi Aksara, 1996. 